\section{Mead and Other Fermented} Beverages

\author{
A.P. Pereira ${ }^{1,2}$, J.M. Oliveira ${ }^{3}$, A. Mendes-Ferreira ${ }^{1,4}$, \\ L.M. Estevinho ${ }^{2 * *}$, A. Mendes-Faia ${ }^{1,4}$ \\ ${ }^{1}$ UNIVERSITY OF TRÁS-OS-MONTES AND ALTO DOURO, VILA REAL, PORTUGAL; \\ ${ }^{2}$ POLYTECHNIC INSTITUTE OF BRAGANÇA, BRAGANÇA, PORTUGAL; ${ }^{3}$ UNIVERSITY OF MINHO, \\ BRAGA, PORTUGAL; ${ }^{4}$ BIOISI, BIOSYSTEMS \& INTEGRATIVE SCIENCES INSTITUTE,
}

LISBOA, PORTUGAL

\subsection{Introduction to Mead}

\subsubsection{Definition, Historical Aspects of Mead, and Perspectives}

Mead is a traditional alcoholic beverage containing an alcoholic strength, by volume, between $8 \%$ and $18 \%$, which results from the alcoholic fermentation of diluted honey by yeasts. It is a popular beverage in eastern Europe (Poland, Slovenia) and in the Baltic states, being also widely consumed in England, Germany, and, especially, in the African countries, for instance, Ethiopia and South Africa. In Portugal mead is still homemade, produced according to the traditional and empirical procedures. This alcoholic beverage is recognized as the oldest consumed by humans, perhaps even before wine, and probably the precursor of beer. It has a long heritage of use for over 5000 years, even though the available archaeological evidence for its production dates back to $7000 \mathrm{BC}$. The first batch of mead probably occurred when it rained into an open pot of honey and the wild yeast did the rest [1]. Pottery vessels containing mixtures of mead, rice, and other fruits with organic compounds of fermentation have been found in northern China; the first known description was found in the Rigveda and dates back to 1700 to 1100 BC [2]. The long tradition of mead consumption led to the coining of the term "honeymoon," because, in addition to being drunk in great quantities at weddings, the newlyweds usually had the practice of drinking mead for one month (a moon) after the ceremony, with the belief that a child would be born 9 months later [3].

Although in the past its use was widespread, the development of civilizations and agricultural resources triggered the replacement of mead by other beverages, like wine and beer, in many areas of the world. In northern Europe, where vines are not cultivated, mead consumption was quite popular until wine was imported at a low cost from the "Corresponding Author. 
southern regions. In the past few years there has been a huge spike in demand, after the drink became fashionable in America. The American Mead Makers Association, an organization dedicated to promoting mead and bringing together mead makers, lists almost 240 mead brewers in the United States and 40 in the rest of the world.

\subsubsection{Mead Styles}

Mead is an alcoholic beverage made by fermenting a mixture of honey and water. Depending on the proportion to which honey is diluted, at 1:0.5, 1:1, 1:2, or 1:3 (honey:water), different types of mead are obtained. Worts that contain a high concentration of sugar $(1: 0.5$ or $1: 1)$ are prepared in fed-batch, successively adding appropriate portions of honey to avoid premature fermentation arrest due to excessive osmotic pressure [4]. A weak or watered mead is called hydromel, and sack mead is a sweeter mead owing to the addition of honey [3]. Using a terminology similar to that used in wine, mead styles are classified as dry, semisweet, or sweet, according to its final sugar concentration [5].

To enhance its character and complexity, a variety of fruits, vegetables, herbs, or spices (ginger, cardamom, cloves, thyme, rosemary, bay leaves, sage, parsley, fennel, cinnamon, nutmeg, lemon or orange peels, among others) may be added to, during, or after fermentation. Traditional mead or show mead is made using either honey from a particular flower source or a multifloral honey. Show mead is produced only by honey's fermentation; nutrients and additives are tolerable but additional spices, fruits, or herbs are not allowed. Regarding traditional mead, small amounts of spices, fruits, or herbs are permitted without ever overpowering the honey flavor or aroma [6].

According to the American Mead Makers Association (www.meadmakers.org) there are several mead styles depending on local traditions and specific recipes. Pyments, cysers, and melomels are types of mead that include the addition of fruit or fruit juices. Pyment is a fermented beverage made from a mixture of grape juice and honey or from a blend of grape wine and mead after fermentation. It has a distinct grape wine character, manifested in acidity, tannin, and other grape characteristics, but the honey character should balance the fruity flavors. Cyser or apple honey cider is made from a mixture of honey and apple juice or cider without additional water. This beverage has a distinct apple character with a pronounced honey aroma, sweet and similar to a sherry. Concerning melomels, these are meads that contain one or a blend of fruits, which contribute with subtle acidic notes to intense, instantly recognizable fruit flavors. Metheglin is mead made with spices and/or herbs, and rhodomel is made from honey and rose petals. Another alcoholic beverage that can be made from honey is braggot, a type of beer made with a mixture of honey and malt, characterized by an aroma of honey and malt, with some bitterness due to the hops. Also, brandies and spirits can be produced from distilling mead. In addition, a sparkling beverage with high amounts of carbon dioxide resulting from a second natural fermentation either in bottle or in tanks may be produced [3]. 


\subsubsection{Mead Product Derivatives}

Honey is produced practically throughout the whole world, $90 \%$ of which is consumed as table honey and $10 \%$ is distributed among the food, cosmetic, and pharmaceutical industries. Different new products may be produced from mead, such as vinegar. In fact, by performing the acetic fermentation of mead, Ilha et al. [7] obtained approximately $5 \mathrm{~L}$ of honey vinegar with $90 \mathrm{~g} / \mathrm{L}$ of acetic acid, using $1 \mathrm{~kg}$ of bee honey as raw material. This honey vinegar showed an acceptability index over $70 \%$ for appearance, color, odor, and flavor, indicating its good consumer acceptability. In South Africa it is possible to find in a meadery, the Makana Meadery, www.iqhilika.co.za, honey mead mustard made by mixing whole grain black mustard with freshly ground yellow mustard and mead vinegar, honey, and salt, resulting in a product with a complex flavor.

\subsection{Characterization of Honey}

Honey is "the natural sweet substance produced by honey bees from the nectar of plants (blossom honey or nectar honey) or from secretions of living parts of plants or excretions of plant sucking insects on the living parts of plants (honeydew honey), which the bees collect, transform by combining with specific substances of their own, deposit, dehydrate, store and leave in the honey comb to ripen and mature" [8]. For a long time in human history, it was an important source of carbohydrates and the only largely available natural sweetener $[9,10]$. In addition to its nutritional properties, honey is one of the products most referred to in old traditional medicine, because of its therapeutic potential in treating respiratory and gastrointestinal illnesses, in healing wounds and burns, and as an antimicrobial agent, among other biological proprieties [11,12].

According to its botanical origin, honey can be classified as monofloral or multifloral, if the bees forage predominantly on one type of plant or several botanical species, respectively [13].

Honey is mainly composed of carbohydrates, lesser amounts of water, and minor components [14] such as minerals, proteins, vitamins, lipids, organic acids, amino acids, phenolic compounds, enzymes, and other phytochemicals [15-17]. Nevertheless, honey composition is rather variable and dependent on the floral source, climate, environmental and seasonal conditions, as well as the handling and processing practices $[11,13,18-24]$.

\subsubsection{Carbohydrates}

Carbohydrates account for about 95-99\% of the dry matter in honey [14,25]. Fructose $(38.2 \%$, mean value) and glucose (mean value of $31.3 \%$ ) are the major carbohydrates in honey, followed by sucrose (mean value of $0.7 \%$ ) [9,14]. Additionally, 25 other oligosaccharides have been detected $[9,14]$, including maltose, isomaltose, trehalose, turanose; trisaccharides erlose, raffinose, and melezitose; and trace amounts of tetra- and 
pentasaccharides, among others $[9,18]$. According to the Codex Alimentarius [8], the minimum concentration of the reducing sugars, glucose and fructose, is $60 \%(w / w)$. The ratio of fructose to glucose is highly dependent on the nectar source [18] and is usually 1.2:1 [26]. The concentration of these sugars influences the sweetness and texture of honey: fructose is sweeter than glucose and honeys with higher ratios of fructose/ glucose remain liquid for longer periods because glucose is less water soluble than fructose $[17,26]$.

\subsubsection{Water}

Water is the second most important component of honey, ranging between $15 \%$ and $20 \%$, with an average value of $17.2 \%$ [9]. The water content of honey depends on several factors: climate conditions, degree of maturity of the hive, and treatments applied during nectar and honey collection and storage $[17,25]$. This parameter will influence its physical properties such as the viscosity [25]. Honey with a high water content usually presents preservation and storage problems because it increases the probability of product fermentation [25]. In fact, low water content contributes to the stability of honey, preventing fermentation and crystallization during storage [24].

\subsubsection{Minerals}

Minerals come from the soil and plants and are present in small amounts ranging from $0.04 \%$, in the clear honeys, to $0.2 \%$, in some dark honeys [18,27]. In addition, other elements may be added during the processes of centrifugation and storage [28]. Potassium is the major mineral, with an average of about one-third of the total [18,25,29-31], followed by calcium, sodium, phosphorus, magnesium, iron, manganese, and copper $[9,25]$. Trace elements like aluminum, iodine, chloride, fluorine, bromine, and barium, among others, are also present in honey [14,32]. The mineral composition depends on the environment, geographic location, and botanical species [18,29,32,33]. In fact, honeys from light blossoms commonly have lower mineral content than dark honeys such as honeydew, chestnut, and heather [29].

\subsubsection{Organic Acids}

Organic acids comprise gluconic acid, resulting from the oxidation of glucose by glucose oxidase [14,25], followed in minor concentrations by pyruvic, malic, citric, succinic, and fumaric acids [14]. These acids account for $0.5 \%$ of the dry matter $[9,25]$, for the acidity, and for the characteristic taste of honey [18]. Honey acidity is also dependent on the botanical species [24] and time of harvest [26]. The presence of osmophilic yeasts adapted to high osmotic pressures, such as high sugar concentrations, may be responsible for the increase in acidity [26]. So, low acidity, below the maximum limit of $50 \mathrm{mmol} / \mathrm{kg}$, indicates the absence of undesirable fermentation [17]. Most honeys are acidic, with pH ranging from 3.4 to 6.1 , and an average value of 3.9 [14,34]. However, this 
parameter is not directly related to the free acidity owing to the buffering capacity of honey [26], which is dependent on phosphates, carbonates, and other minerals of honey.

\subsubsection{Nitrogen Compounds}

Amino acids, peptides, proteins, and nucleic acid derivatives are the major nitrogenous substances in honey. The amino acid content corresponds to about $10 \mathrm{~g} / \mathrm{kg}$ [32]. The amino acid composition of honey is highly variable depending on its origin, thus the amino acid profile is a good indicator of the botanical and geographical origin of honey $[18,22,32]$. Proline is the major amino acid in honey, corresponding to values between $50 \%$ and $85 \%$ of total free amino acids [18,32]. Proline content should be above $200 \mathrm{mg} / \mathrm{kg}$; values below $180 \mathrm{mg} / \mathrm{kg}$ indicate potential adulteration of the honey by sugar addition [14]. In addition to proline, 26 other amino acids have been identified in honey: glutamic acid, aspartic acid, glutamine, histidine, glycine, arginine, tryptophan, and cysteine, among others [18,32]. The protein content is relatively low, approximately 2 to $4 \mathrm{~g} / \mathrm{kg}$ [14]. Proteins in honey are mainly enzymes: invertase, diastase, glucose oxidase, catalase [18], $\alpha$-glucosidase, $\beta$-glucosidase [35]. Some enzymes come from the bees during the process of honey ripening [14]. The enzymes diastase and invertase are important for assessing honey quality, because they are used as indicators of honey freshness. Diastase catalyzes the hydrolysis of starch into disaccharides and monosaccharides and it is relatively stable to heat and storage, and invertase catalyzes the hydrolysis of sucrose to glucose and fructose. Hydrogen peroxide, $\mathrm{H}_{2} \mathrm{O}_{2}$, the antibacterial factor found in honey, is regulated by the enzymes glucose oxidase and catalase. Thus, the enzymatic activity may indicate exposure to heat during processing and storage of the honey [14].

\subsubsection{Vitamins}

The vitamin content in honey is low and varies with the floral origin [36]. Most are watersoluble vitamins owing to the aqueous nature of honey and a low percentage of lipids [37]. Vitamins $C$ (ascorbic acid), $B_{1}$ (thiamine), $B_{2}$ (riboflavin), $B_{6}$ (pyridoxine), $B_{3}$ (niacin), $\mathrm{B}_{5}$ (pantothenic acid), and $\mathrm{K}$ (phyllochinon) have been reported in honey $[9,25,32,37]$. Ascorbic acid is the main vitamin found in honey, with concentrations ranging from 22 to $25 \mathrm{mg} / \mathrm{kg}$ [9] and it is found in almost all honeys. On the other hand, Ciulu et al. [36] observed a marked association between the concentration of vitamins $B_{3}$ and $\mathrm{B}_{5}$ and the botanical origin of the product.

\subsubsection{Phenolic Compounds}

Honey contains a diversity of phenolic compounds as secondary constituents, such as flavonoids, phenolic acids, and phenolic acid derivatives. The main polyphenols are the flavonoids, in concentrations that can vary between 0.6 and $4.6 \mathrm{~g} / \mathrm{kg}$, and are mainly found in honey produced under dry and high-temperature conditions [9]. The flavonoids 
present in honey are essentially flavanones and flavones, namely myricetin, tricetin, quercetin, hesperetin, lutein, kaempferol, pinocembrin, chrysin, pinobanksin, genkwanin, galangin, apigenin, and naringenin $[9,15,18,19,21,38,39]$. The phenolic acids are found in concentrations ranging from 0.01 to $10 \mathrm{mg} / \mathrm{kg}$ [18]. The predominant phenolic acids are gallic and $p$-coumaric, with caffeic, ferulic, chlorogenic, ellagic, syringic, vanillic, $p$-hydroxybenzoic, and cinnamic acids being minor constituents $[15,21,38,40]$.

The composition in flavonoids of some honeys, such as heather, citrus, or chestnut, can be used for determining its botanical origin [40,41]. Dark-colored honeys contain more phenolic acid derivatives but fewer flavonoids than light-colored ones [14]. In fact, heather honeys are characterized by high concentrations of benzoic, phenylacetic, mandelic, and $\beta$-phenyllactic acids [18]. Considerable differences in composition and concentration of phenolic among monofloral honeys have also been found [14]. For instance, hesperetin proved to be a useful marker for the floral origin of citrus honey; kaempferol is a marker for rosemary honey, abscisic acid for heather honey, and homogentisic acid for strawberry tree (Arbutus unedo) honey [40].

The phenolic content of honey is highly related to its bioactive properties, namely antioxidant and antimicrobial activities. The antioxidant activity of honey has been reported by numerous authors [11,24,42-47]. Others have provided evidence of antibacterial activity of honey against pathogenic bacteria resistant to antibiotics [48-55] and against food spoilage bacteria [56].

\subsubsection{Volatile Compounds}

Volatile compounds of honey are derived from the botanical species or nectar source, from the transformation process carried out by bees, from heating or handling during processing and storage, or from microbial and environmental contamination $[14,57,58]$.

Aroma compounds are present at very low concentrations, mainly as complex mixtures of volatile components with different functionality and relatively low molecular weight [59]. Indeed, more than 300 volatile compounds have been identified in different honeys, including hydrocarbons, aldehydes, alcohols, ketones, acids, esters, benzene derivatives, furans and pyrans, norisoprenoids, terpenes, and sulfur compounds [58,60,61].

Usually, monofloral honeys possess highly individual aroma profiles compared to multifloral ones [62]. The volatile profile represents a chemical fingerprint of monofloral honey because the nature and amount of volatile compounds are related to the floral source $[41,63,64]$. So, the determination of volatile compounds has been used to differentiate honeys according to botanical origin $[57,61,63-65]$ and geographical origin [65-67]. The differences between the geographic sources can be attributed to climatic conditions and to the surrounding flora; nevertheless, the volatile compounds seem to contribute more to the differentiation of honey according to botanical origin than to country of origin [68]. In fact, a considerable number of volatiles have been suggested as possible markers of the following monofloral honeys: acacia, chestnut, eucalyptus, 
heather, lime, and sunflower [69]; strawberry tree [70]; thyme [71]; and citrus, eucalyptus, and lavender [41,61]. For example, carvacrol and $\alpha$-terpinene seem to be important in tilia honey, $\alpha$-pinene and 3-methyl-2-butanol in sunflower, and cis-linalool oxide in acacia honey [68].

\subsubsection{Color}

The determination of honey color is a useful classification criterion for monofloral honeys, because it is related to the contents of phenolics, flavonoids, and minerals $[15,21,32,72]$. The mineral content influences the color and the taste; honeys with higher quantity of minerals have darker color and stronger taste [33]. The color of honey also depends on the processing, temperature, and/or time of storage [25] and can range from white-water, extrawhite, white, extraclear amber, light amber, amber, to dark amber [15]. However, it is important to ascertain that the color's intensity increases during storage owing to Maillard reactions, caramelization of fructose, and reactions with polyphenolic compounds $[15,73]$.

\subsubsection{The Natural Microbiota of Honey}

The microbial population of honey includes microorganisms that come from the environment, soil, plants, and pollen and those that usually colonize the digestive tract of bees (primary sources of contamination) $[25,74,75]$. Thus, the microbial population of honey includes fungi (yeasts and molds) and spore-forming bacteria [74,75]. The intestine of bees contains high numbers of gram-positive bacteria (Bacillus, Bacteridium, Streptococcus, and Clostridium spp.) and gram-negative bacteria (Achromobacter, Citrobacter, Enterobacter, Erwinia, Escherichia coli, Flavobacterium, Klebsiella, Proteus, and Pseudomonas) and lower numbers of yeasts [76]. Additionally, microbial contamination may also have an origin in secondary sources, such as human handling, containers and equipment, insects, animals, and water [74,75]. Possible routes of microbial contamination include air (during packaging), handlers (from skin infections and fecal contamination), cross-contamination (from animals or animal products), and equipment (including residues of food and water) [75]. Whereas primary sources of contamination are very difficult to control, the secondary sources can be controlled with proper hygiene and good manufacturing practices.

The survival of microorganisms is influenced by honey's chemical composition, particularly by the low water content. Indeed, this parameter hampers microbial growth, especially of bacteria, which are generally less tolerant to high osmotic pressure, compared to fungi [25]. Also, the low $\mathrm{pH}$ and high sugar content play key roles in the survival and growth of microorganisms $[14,34,76]$.

Even though bacteria can survive in this natural product, they are unlikely to replicate [75]. As a consequence, the detection of high numbers of vegetative bacteria might be indicative of recent contamination by a secondary source [34]. The consumption of honey contaminated with Clostridium botulinum spores is especially dangerous for 
infants and children, with many reported cases of infant botulism. Although honey itself does not contain the toxin, the spores can theoretically build the toxin after digestion in infants until 1 year old [14].

Molds, or filamentous fungi, normally associated with honey include the genera Penicillium, Aspergillus, Cladosporium, Penicillium, and Mucor [74,77]. These microorganisms can survive but do not tend to grow in honey [75]. The species Bettsya alvei, Ascosphaera apis, and Ascosphaera major may indicate recent contamination by inadequate bee hive management practices [17].

Honey naturally contains various osmotolerant/osmophilic yeasts that grow at low $\mathrm{pH}$ values and are not inhibited by high osmotic pressure. Most yeasts isolated from this environment include species of the genera Saccharomyces, Debaryomyces, Hansenula, Lipomyces, Pichia, Schizosaccharomyces, Torula, and Zygosaccharomyces [75]. Although studies on the quantification of yeast in honey are scarce, the values reported are normally low. In fact, less than $10 \mathrm{cfu}$ of yeasts per gram was found in honeys of Central Argentina [17] and an average of $12 \mathrm{cfu} / \mathrm{g}$ in crude honey from India [78], whereas in honey from Brazil the number of yeasts varied from $5 \times 10^{2}$ [79] to $1.5 \times 10^{5} \mathrm{cfu} / \mathrm{g}$ [80]

Osmophilic or osmotolerant yeasts have the ability to convert honey's glucose and fructose into ethanol, carbon dioxide, and acids, making the product unsuitable for consumption. According to the literature, honey should meet the following quality criteria: maximum yeast count of $5 \times 10^{4} \mathrm{cfu} / \mathrm{g}$ and maximum glycerol content of $300 \mathrm{mg} / \mathrm{kg}$; ethanol concentration should be less than $150 \mathrm{mg} / \mathrm{kg}$ [14]. Honey with moisture content less than $17.1 \%$ is safe from fermentation risk regardless of yeast count; however, a value above $20 \%$ means that the honey is always in danger of fermentation occurring [14].

\subsection{Mead Production}

The production of mead involves several steps that are presented in the diagram of Fig. 14.1.

Initially, honey is diluted with water in a proportion that depends on the type of mead desired. In most processes, honey must starts at between 20 and $23^{\circ} \mathrm{Bx}$ [5,81-89]. Spices or herbs can be added, either as an extract or directly, prior to or during the process [3].

After dilution, a mixture of nutrients, nitrogen, minerals, and growth factors may be added if necessary, to stimulate yeast growth and fermentation. Also the adjustment of acidity may be done to obtain a better balance between sweetness and acidity. In general, the acids used for honey must adjustment are citric acid [4], malic acid [83-86], or tartaric acid $[88,90]$. A mixture of tartaric and malic acids may be used not only to adjust the acidity but also to increase the buffer capacity of honey must [82]. The must is subsequently sanitized, pasteurization being one of the most commonly used methods [82-86,89]. In contrast, other techniques are used with the aim of controlling or inactivating most wild microorganisms, including the addition of potassium metabisulfite 


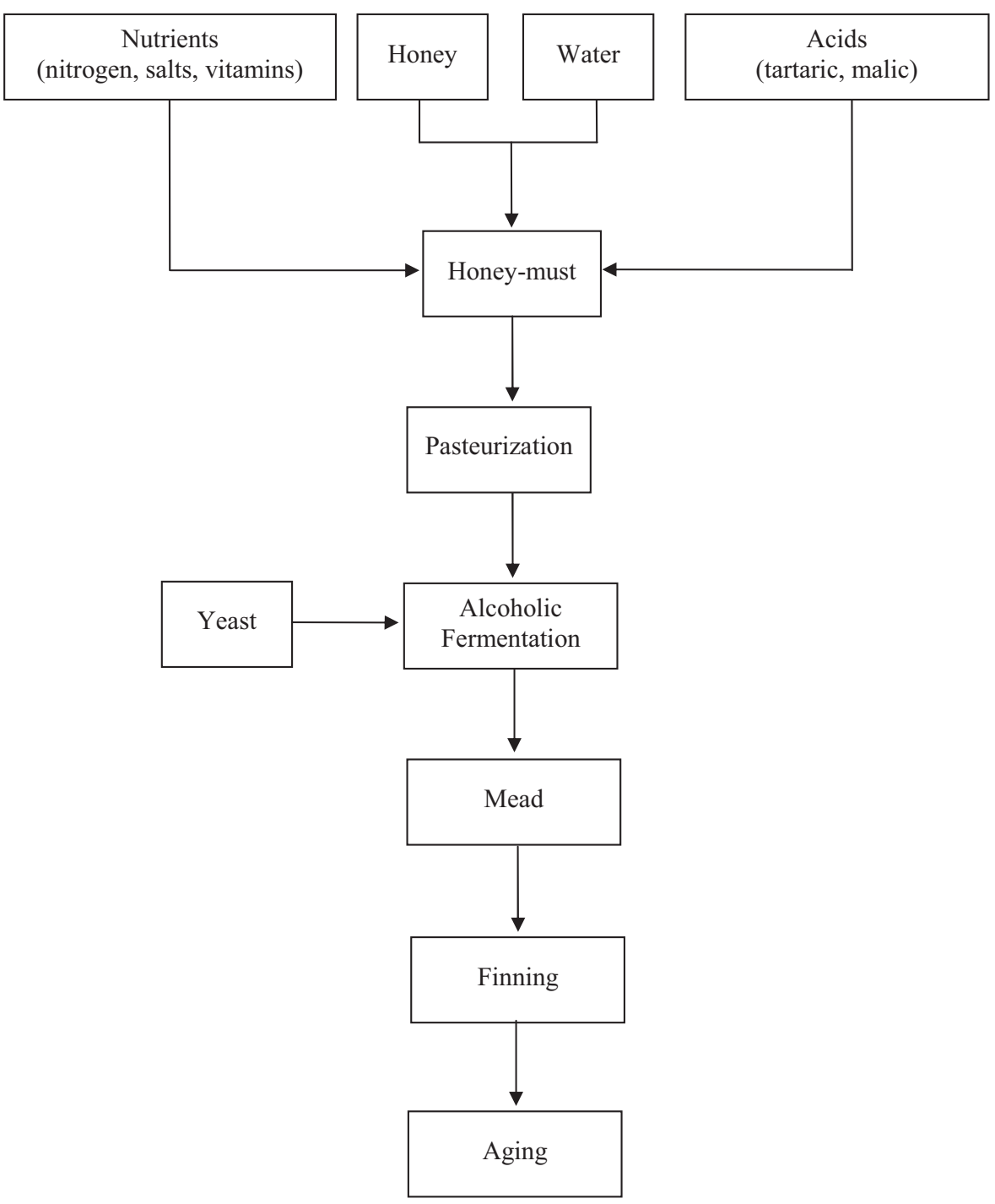

FIGURE 14.1 Diagram of mead production.

[88] and sulfur dioxide [90-92] or boiling of the must [4,92,93]. After the honey must treatment, it is inoculated with selected strains of Saccharomyces cerevisiae from culture collections or active dry yeasts available on the market. Fermentation is conducted at temperatures ranging from 22 to $25^{\circ} \mathrm{C}$ and is monitored daily to reduce the risk of premature fermentation arrest. The duration of fermentation depends on the type of honey, the nutrients added to the honey must, the size of the inoculum, and the fermentation conditions. After completion of alcoholic fermentation, the mead must be clarified by centrifugation or by using fining agents, such as bentonite, isinglass, egg 
white, gelatin, and casein, and filtered before bottling. Fining agents are applied to obtain limpid and clear mead, eliminating substances in suspense as well as protein instability [94]. Aging is important in mead production, particularly for the development of favorable aroma compounds, generally moving from a harsh, acidic, unpleasant taste to a smooth to a mellow beverage with a nice bouquet and fragrance [3]. The length of aging can be from months to years, depending on the type of mead. In general, lighter meads will be ready sooner and darker, sweet meads and those with higher alcohol content will need more time to fully develop [3].

\subsubsection{Control of Honey Must Fermentation}

Saccharomyces cerevisiae metabolizes glucose and fructose through the EmbdenMeyerhof pathway with the formation of $2 \mathrm{~mol}$ of pyruvate per mole of hexose. The pyruvate is decarboxylated by pyruvate decarboxylase to acetaldehyde, which is reduced to ethanol with the concomitant oxidation of NADH coenzyme formed in the oxidation of glyceraldehyde 3-phosphate to 1,3-diphosphoglyceric acid. The effective ethanol yield depends on the strain, as well as on the fermentative conditions, among which are the temperature and the must composition. In addition to ethanol, S. cerevisiae produces small amounts of glycerol, higher alcohols, diacetyl, acetoin, 2,3-butanediol, succinic acid, and traces of acetic acid, lactic acid, and acetaldehyde [95-97], which have a strong impact on final taste and aroma composition.

Despite the excellent properties of honey, mead production faces several problems, namely, slow or premature fermentation arrest, lack of uniformity of the final product, and production of yeast off-flavors. Many factors might be related to these problems, such as honey variety, medium composition (vitamin, minerals, and nitrogen content), fermentative yeast, and fermentation conditions (temperature and $\mathrm{pH}$ ) [98].

The influence of the honey type has been evaluated in mead production [90]. Light honey, in comparison to dark, has a deficiency in the amount of nitrogen compounds and in the content of minerals that must be fulfilled by supplementation, taking into account the yeast's requirements.

\subsubsection{Yeasts}

The unpredictable nature of spontaneous fermentation and stock fermentation may be associated with the risk of undesirable flavor occurrence [81]. Hence, inoculation with selected yeasts is a common practice to control the nature and quantity of fermentation products, particularly metabolites that impair the final quality of the product. The yeasts used in mead production are usually strains of $S$. cerevisiae with suitable characteristics as required for wine and beer production: vigorous fermentative activity, tolerance to ethanol and sulfur dioxide, tolerance to temperature variation, and ability to flocculate easily after completion of fermentation. In a previous work, the fermentative abilities of five strains of $S$. cerevisiae isolated from Portuguese honey were compared to those of a commercial wine strain [90]. According to the results, the performance of the strains isolated from 
honey was similar to that observed in those available on the market, which are used in the production of other beverages. Even though most mead is produced using commercial yeast strains, the traditional mead produced in some African countries still uses natural fermentation conducted by microorganisms initially present in the substrates and fermentation equipment. Fortunately, the yeasts S. cerevisiae [99] and Kluyveromyces bulgaricus [100] appear to be the dominant microorganisms in this traditional beverage.

In wine, mixed culture fermentation has been exploited to enhance aroma and flavor and to obtain different types and styles of the product [101]. This practice has been tested in mead production by Chen et al. [81], who successfully used multiple yeast inoculations with different strains.

The use of a reduced inoculum of $S$. cerevisiae can be associated with sluggish and stuck fermentations [102]. So, to provide evidence for this claim, Pereira et al. [83] studied the effect of the inoculum size on yeast fermentation performance, as well as on mead composition and the volatile compounds production. Increasing the pitching rate resulted in significant fermentation time saving, even though high inocula could lead to lower production of desirable aromatic compounds.

\subsubsection{Nutrient Supplementation}

The problems of honey must fermentation are considered to be due to a deficiency of nitrogen, minerals, and other growth factors [2]. The correction of these nutritional deficiencies may reduce stress sensitivity of the yeast, improving fermentation performance [103].

Vitamins, whose concentration is not usually limiting, are required by yeast cells for many enzymatic reactions [104,105]. Minerals are required as cofactors for several metabolic pathways influencing the rate of sugar conversion [106]. Nevertheless, nitrogen deficiency has been reported as the major cause of stuck or sluggish fermentation of grape juice $[96,107]$, because nitrogen affects yeast growth, yeast fermentation rate, and fermentation length [108]. Nitrogen concentration also regulates the formation of byproducts, such as $\mathrm{H}_{2} \mathrm{~S}$, fatty acids, higher alcohols, and esters, among others, which affect the chemical and sensorial proprieties of the alcoholic beverage [96,109,110]. In alcoholic fermentation, S. cerevisiae normally requires a minimum of $267 \mathrm{mg} / \mathrm{L}$, expressed as nitrogen, for complete fermentation of a must containing $200 \mathrm{~g} / \mathrm{L}$ hexoses (glucose plus fructose), in an industrially reasonable time [111]. Despite this, there are differences in the nitrogen demand according to the industrial yeast strain or the quality of the nitrogen source or the must sugar concentration [112,113].

Taking into account all the knowledge used in wine production, honey must was optimized by supplementing it with potassium tartrate, malic acid, and diammonium phosphate (DAP) and fermentation time was reduced to 11 days [82]. Even under these improved conditions, the available sugars were not completely consumed by yeasts and a certain amount of residual assimilable nitrogen remained in all of the meads, even in controls to which no nitrogen was added, suggesting that other factors could account for the reduced yeast activity in honey must fermentation. In addition to reducing the 
fermentation length and increasing specific growth rate of yeasts, the addition of DAP to honey must can contribute to the enhancement of the fruity character of mead [86].

In fact, the supplementation of nitrogen deficiencies with DAP addition is a widespread practice in mead production [5,7,83-85]. In other cases, the honey must nutritional deficiencies are supplemented in the form of commercial nutrients $[89,90,93]$. In the fermentation of longan mead, Chen et al. [81] found that the addition of commercial nutrients containing yeast hulls, yeast extract, DAP, vitamin $\mathrm{B}_{1}$, magnesium sulfate, folic acid, niacin, and calcium pantothenate only attained high fermentation rates. Also using commercial nutrients, Gomes et al. [91] detected high sugar consumption and high production of ethanol, acetic acid, and glycerol with a concentration of $0.88 \mathrm{~g} / \mathrm{L}$.

There are references in literature to other natural supplements that can be added to mead to improve yeast growth or yeast fermentative activity: black rice, a natural nutrient for yeast, as a source of fungal glucoamylase [99,114]; fruit juices as a source of acids and growth factors [2]; or even pollen [88]. In this study, the addition of pollen improved fermentation rates, ethanol yield, and final sensory attributes.

\subsubsection{Yeasts Immobilization in Mead Production}

Whole-cell immobilization may be defined as the physical confinement or localization of intact cells to a certain defined region of space with the preservation of some desired catalytic activity [115]. Methods to immobilize microorganisms have gained attention in the past few decades and are being successfully applied in alcoholic beverage production. The use of these techniques has made it possible to reduce labor requirements, to simplify time-consuming procedures, and thereby to reduce costs [116].

So, to be attractive for industrial purposes the methodology must be robust, not susceptible to contamination, able to impart correct flavor changes to the beverage, not liable to cause oxidation of the product, and able to use commercially acceptable supports and organisms [116].

To obtain the desired product it is fundamental to select a suitable support for cell immobilization, and the choice depends on the process in which it will be applied as well as the process conditions [117]. Generally, four major categories of immobilization techniques can be distinguished, based on the physical mechanism employed: attachment or adsorption on solid carrier surfaces, entrapment within a porous matrix, selfaggregation by flocculation (natural) or with cross-linking agents (artificially induced), and cell containment behind barriers [117,118].

In comparison with free cells, the immobilization may induce alterations in cell growth, physiology, and metabolic activity and may affect their tolerance to stress factors and the formation of aroma compounds. Mass transfer limitations by diffusion, disturbances in the growth pattern, surface tension and osmotic pressure effects, reduced water activity, cell-tocell communication, changes in the cell morphology, and altered membrane permeability are some factors considered responsible for alterations through immobilization [115].

Immobilized yeast cells have not been widely used in mead production. Indeed, only a few studies have been reported on this theme. To our knowledge, the pioneer work on 
this matter was conducted by Qureshi and Tamhane [119] using whole cells of S. cerevisiae immobilized in calcium alginate gels to produce mead. The optimum $\mathrm{pH}$ for alcohol production was 4.5 or 5.5 when free or immobilized cells, respectively, were used. The authors produced mead for a period of more than 3 months using immobilized cells, thus reducing the problems of contamination and secondary fermentation associated with traditional mead production. Later, the same authors [87] used two series reactors separately packed with immobilized cells of S. cerevisiae and Hansenula anomala to produce meads of controlled quality and reduced the time period of production and eliminated the costlier aging process.

Navrátil et al. [93] used a two-column packed-bed system with an entrapped ethanoltolerant distillery yeast of $S$. cerevisiae to provide higher ethanol productivity and thus to make the process more efficient. Yeast cells were immobilized in calcium pectate, which has higher mechanical stability than calcium alginate. The system enabled an increase in the fermentation rate and mead to be produced in a continuous mode.

The capacity of two sodium alginate concentrations, $2 \%$ and $4 \%$, to immobilize $S$. cerevisiae yeast strains QA23 and ICV D47 in the context of mead production was investigated by Pereira et al. [84]. Neither of the alginate concentrations was able to prevent cell leakage from the beads. Even so, at the end of the fermentation, the number of cells entrapped in the beads was higher than the number of free cells, and the total $4 \%$ alginate bead wet weight was significantly higher than the $2 \%$ alginate bead wet weight. The fermentation length was $120 \mathrm{~h}$ for both yeast strains and the evaluation of mead quality showed that the yeast strain had significantly more influence on the physicochemical characteristics than the alginate concentration.

To avoid cell leakage, the potential of application of immobilized yeast cells on singlelayer $\mathrm{Ca}$-alginate or double-layer alginate-chitosan was assessed for mead production [85]. Minor differences were detected in the fermentation length and in the rate between fermentations conducted with free or immobilized cells, even though higher concentrations of viable cells were achieved in immobilized systems. The double-layer alginate-chitosan had no advantage compared with the single-layer $\mathrm{Ca}$-alginate, as the numbers of free cells in the medium resulting from cell leakage were similar. Meads obtained with entrapped yeast cells presented less ethanol and glycerol and more acetic acid, presenting larger amounts of volatile compounds. Immobilized cells produced meads with higher concentrations of fruity characteristic compounds such as ethyl octanoate and ethyl hexanoate; however, the concentrations of undesirable compounds, namely ethyl acetate and octanoic and hexanoic acids, in such meads were also higher.

\subsection{Aroma of Mead}

The aroma profile is one of the most typical features of a food product, for both its organoleptic quality and its authenticity [32]. The aroma of mead has contributions from honey, inoculated yeast, and technological processes $[2,81,83,85,86]$. 


\subsubsection{Honey-Derived Volatiles}

The honey quality, which is crucial in the consumer's assessment, is strongly dependent on the botanical and geographical origin of the product $[9,58]$. Honey aroma is very complex and involves several volatile compounds; however, not all have a significant impact on the aroma. In general, the impact of a given compound depends on the extent to which the concentration exceeds its odor threshold. It is important to state that some synergistic and/or antagonistic interactions between various components may occur, and thus, even compounds present in low concentrations may contribute to honey aroma $[58,62]$. To determine the influence of the volatile compounds on overall honey aroma, odor activity values (OAVs) should be assessed by dividing the concentration of each compound by its perception threshold. Only the compounds with OAVs greater than 1 (or near) may have contributed to the honey aroma [58]. The same volatile compounds identified in various honey samples can be characterized by a wide range of aroma descriptors, for example, from bitter, rancid, or fishy to sweet and flowery (Table 14.1).

Sensory evaluation, based mainly on attributes of aroma and taste, is one of the most useful tools in honey characterization $[61,120,121]$. Some of the aroma attributes proposed have been floral, fruity, candy, waxy, resin, wood, citric, acidic, spicy, balsamic, caramel, herbaceous, coffee/chocolate, cheese, chemical, and fermented, among others. The attributes sweet, acid, astringent, ripe fruit, toasty caramel, woody, and spicy have been selected for taste characterization. Honeys from different geographical and botanic origins differ regarding their sensory profile. For instance, the attributes flowery, fruity, waxy, jaggery-like, chemical, and caramel notes were the major variables among honey samples from India [120]. Castro-Vázquez et al. [61] identified the volatile compounds and the sensory descriptors that are more representative of different monofloral honeys, namely, citrus, rosemary, eucalyptus, lavender, thyme, and heather. These authors verified that citrus honeys were characterized by higher amounts of linalool derivatives and by fresh fruit and citric aromas; eucalyptus honeys had hydroxyketones and $p$-cymene derivatives together with cheese and hay aromas; lavender honeys had mainly hexanal, nerolidol oxide, and coumarin and the sensorial attributes balsamic and aromatic herbs aromas; finally, heather honeys were characterized by high contents of benzene and phenolic compounds and ripe fruit and spicy aromas. Regarding chestnut honeys from Spain it was verified that the volatile composition and sensory profile are greatly influenced by the geographic origin, i.e., honeys from the Spanish northeast presented significantly higher concentrations of aldehydes, alcohols, lactones, and volatile phenols, which are associated with herbaceous, woody, and spicy notes; honeys from the northwest area showed superior levels of terpenes, esters, and some benzene derivatives, closely related to honey-like, floral, and fruity notes [121].

\subsubsection{Fermentation Yeast-Derived Volatiles}

During alcoholic fermentation, yeasts produce a range of compounds with strong sensorial importance to the quality of the final product. Fermentative compounds, 
Table 14.1 Odor Descriptors of Some Volatile Compounds Found in Honeys

\begin{tabular}{ll}
\hline Volatile Compound & Odor Descriptors \\
\hline Benzaldehyde & Bitter almond; fragrant; aromatic; sweet; marzipan \\
Benzene acetaldehyde & Harsh; green \\
$\gamma$-Butyrolactone & Woody; toasty; caramel \\
Carvacrol & Pungent; warm \\
$p$-Cymenene & Citrus; pine \\
$\beta$-Damascenone & Fruity; sweet; honey \\
Decanal & Strong; sweet; orange peel odor; citrus taste; soap; fat \\
Dimethyl disulfide & Vegetable; cabbage; putrid \\
Dimethyl sulfide & Cabbage; sulfuric; gasoline; sweet; honey; acrid; cooked vegetables \\
Dimethyl trisulfide & Powerful; fish; diffusive \\
Ethyl acetate & Ethereal; sharp; wine-brandy-like; reminiscent of pineapple \\
Ethyl butyrate & Sweet; fruity; pineapple \\
Furfural & Bread; almond; sweet; woody; fragrant; fruity; cherry \\
Heptanoic acid & Rancid; sour; sweet-like; fatty \\
Hexanol & Balsamic; aromatic herb \\
Hotrienol & Hyacinth; balsamic; aromatic herb \\
Isophorone and ketoisophorone & Spicy \\
Lilac aldehyde & Flowery; fresh \\
Linalool & Sweet; floral; lavender; refreshing; citrus; orange; forest; geranium \\
2-Methylbutanal & Sweet; musty; aldehydic \\
3-Methylbutanal & Sweet; musty; aldehydic \\
Nonanal & Citrus; fatty; floral; green \\
Nonanol & Green; sweet; oily \\
Oak lactone & Woody; toasty; caramel \\
Octanal & Fat; soap; lemon; green \\
Pantolactone & Woody; toasty; caramel \\
Phenylacetaldehyde & Sweet; honey-like \\
2-Phenylethyl acetate & Flowery; sweet; champagne \\
Sinensal & Sweet; orange \\
Spathulenol & Cheese; hay \\
\hline CE. Manyi-tong & \\
\hline
\end{tabular}

C.E. Manyi-Loh, R.N. Ndip, A.M. Clarke, Volatile compounds in honey: a review on their involvement in aroma, botanical origin determination and potential biomedical activities, International Journal of Molecular Sciences 12 (2011) 9514-9532; V. Kaškonienė, P.R. Venskutonis, Floral markers in honey of various botanical and geographic origins: a review. Comprehensive Reviews in Food Science and Food Safety 9 (2010) 620-634.

resulting from the metabolic activity of yeasts, represent quantitatively the majority of volatile compounds in wines [122]; therefore these microorganisms play an important role in the development of wine aroma. Since 2005, some research has been conducted on volatile compounds formation during mead fermentation. The production of volatile compounds is affected by several factors, including the yeast strain [81,99], cell condition (free or immobilized) [85], and inoculum size [83], as well as by the fermentation conditions [89]. In addition, the type of honey [89,123,124], and the honey must composition/formulation $[4,82,86,88]$ can also modulate the formation of volatile compounds. 
The volatile compounds produced by yeasts are alcohols, organic acids, esters, volatile fatty acids, carbonyl compounds, and volatile phenols, among others.

\subsubsection{Alcohols}

Alcohols are secondary yeast metabolites and, from a quantitative point of view, are the most important group of volatile compounds produced by yeast during alcoholic fermentation of sugars $[125,126]$, inclusive in mead production $[82,83,85,86,88]$. Alcohols include 2-methyl-1-propanol (isobutanol), 2-methyl-1-butanol, 3-methyl-1-butanol (isoamyl alcohol), and 2-phenylethanol (with pleasant rose-like aroma), among others $[125,126]$. The most predominant alcohol in some meads has been 3-methyl-1-butanol, in concentration ranging from 90 to $350 \mathrm{mg} / \mathrm{L}$ [81-83,85,86,88,89,99], above the odor threshold of $30 \mathrm{mg} / \mathrm{L}[127,128]$. In comparison, lower concentrations of 3-methyl-1butanol were found in Slovak and South African meads [123]. Other secondary predominant alcohols present in mead are 2-methyl-1-butanol, 2-methyl-1-propanol, 1-propanol, and 2-phenylethanol [82,83,85,86,88,89,99,124].

Generally, concentrations of alcohols in mead are below $300 \mathrm{mg} / \mathrm{L}$. Excessive concentrations, above $400 \mathrm{mg} / \mathrm{L}$, may have negative impacts on the aroma and flavor, resulting in a strong, pungent smell and taste [125]. Mendes-Ferreira et al. [82] verified an inverse correlation between higher alcohols and nitrogen levels in mead, and Roldán et al. [88] found an increase in alcohols with pollen addition to the honey must. Moreover, the immobilization of yeast cells of $S$. cerevisiae seems to enhance the production of 1-propanol [85].

\subsubsection{Esters}

Esters are derived from a reaction between organic or volatile fatty acids and ethanol (ethyl esters) or between acetic acid and higher alcohols (acetates), being largely responsible for the fruitiness of wine and fermented beverages, and therefore they play an important role in the sensory composition of the related young products $[82,83,126]$. Ethyl acetate is quantitatively the most important ester found in mead produced in Portugal [82,83,85,86], Slovakia and South Africa [123], Spain [88], Slovenia [124], and southwest Ethiopia [99]. Ethyl acetate is an ester compound with a solvent-like odor $[129,130]$ and an odor threshold of $12.3 \mathrm{mg} / \mathrm{L}$ [131]. Other esters found in mead in minor amounts are isoamyl acetate, 2-phenylethyl acetate, ethyl butyrate, ethyl hexanoate, and ethyl octanoate. These esters have pear-drop aromas (isoamyl acetate); honey, fruity, flowery aromas (2-phenylethyl acetate); and fruity, sweet aromas (ethyl butyrate, ethyl hexanoate, and ethyl octanoate) [129]. However, high variability in the concentration of these compounds is observed between meads, probably because different commercial yeast strains can produce variable amounts [125].

Ester production by yeasts increases with nitrogen concentration [82], with the addition of nutrients to the honey must, like pollen [88], and in mead fermented with yeast cells immobilized in single-layer of alginate or double layer of alginatechitosan [85]. 


\subsubsection{Volatile Fatty Acids}

Volatile fatty acids include a mixture of straight-chain fatty acids, resulting from $\beta$-oxidation of fatty acids, usually referred to as short-chain $(\mathrm{C} 2-\mathrm{C} 4)$, medium-chain (C6-C10), long-chain (C12-C18), and a group of branched-chain fatty acids, from the metabolism of the amino acids [126]. Acetic acid is quantitatively and sensorily the most important volatile fatty acid produced during alcoholic fermentation, accounting for more than $90 \%$ of the total volatile acidity [129]. Acetic acid at elevated concentrations imparts a vinegar-like character and it becomes objectionable at concentrations of 0.7 to $1.1 \mathrm{~g} / \mathrm{L}$, the optimal concentration being between 0.2 and $0.7 \mathrm{~g} / \mathrm{L}$ [125]. In mead, concentrations of acetic acid less than $0.6 \mathrm{~g} / \mathrm{L}$ have been reported $[4,85,90]$, although Švecová et al. [132] found concentrations above $1 \mathrm{~g} / \mathrm{L}$ in Czech meads. Volatile acidity increases during fermentation mainly as a result of acetic acid synthesis. So, values ranging between 0.4 and $4 \mathrm{~g} / \mathrm{L}$ have been reported in mead [82,83,85,86,88,89,123]. As the fatty chain length increases, the volatility decreases and the odor changes from sour to rancid and cheese [126], characteristic of the compounds hexanoic, octanoic, and decanoic acids. Generally, octanoic acid is the main fatty acid in mead, followed by hexanoic and decanoic acids $[82,83,85,88]$. This fatty acid has an odor threshold of $0.5 \mathrm{mg} / \mathrm{L}$ [133] and its amount in mead can vary from 0.1 [88] to $6 \mathrm{mg} / \mathrm{L}$ [82]. On the other hand, Sroka and Tuszyński [4] verified that decanoic acid was in higher amounts in mead than octanoic and dodecanoic acids, but all of them were at concentrations below $30 \mathrm{mg} / \mathrm{L}$. The concentration of medium-chain fatty acids was higher in meads supplemented with nitrogen compared to nonsupplemented fermentations $[82,86,88]$.

\subsubsection{Carbonyl Compounds}

Yeasts produce various carbonyl compounds from sugar metabolism, acetaldehyde being quantitatively the most important, constituting more than $90 \%$ of the total aldehydes in wines and other alcoholic fermented beverages [134]. It contributes with "bruised apple" and "nutty" characters, when present at sensorily detectable concentrations, but can also be a sign of wine oxidation $[125,126]$. This compound has been found in meads produced by $S$. cerevisiae in concentrations between 5 and $30 \mathrm{mg} / \mathrm{L}$ $[83,85,86,88]$, always above its perception threshold of $0.5 \mathrm{mg} / \mathrm{L}$ [127]. However, considerably higher concentrations of this compound were obtained for mead produced by any other yeast species, Saccharomyces bayanus, either in lime mead (608 mg/L) or in chestnut mead $(1370 \mathrm{mg} / \mathrm{L})$ [124]. In addition, the concentration of this compound appears to be related to the must composition, increasing with the addition of pollen [88] and nitrogen [86].

\subsubsection{Volatile Phenols}

Volatile phenols have a relatively low detection threshold and are, therefore, easily detected owing to their pharmaceutical odor [125]. Although they can contribute positively to the aroma of some wines, they are better known as off-flavors such "Band-Aid," "barnyard," or "stable" [129]. The most important volatile phenols are the ethylphenols, 
4-ethylguaiacol and 4-ethylphenol, and the vinylphenols, 4-vinylguaiacol and 4 -vinylphenol. Higher concentrations of 4-vinylphenol than 4-vinylguaiacol have been found in mead produced with a multifloral dark Portuguese honey, but in concentrations below their detection thresholds $[83,85,86]$. This production was not affected by the yeast strain. Also in buckwheat and soy mead 4-methylphenol was detected, but again, in concentrations below the odor threshold [89].

Because beverages can contain a very complex set of volatile compounds, to estimate the contribution of an individual compound to the overall aroma it is important to determine the OAV [135]. The volatile compounds with more influence on the mead aroma profile are the alcohols (3-methyl-1-butanol and 2-phenylethanol), esters (mainly ethyl acetate, isoamyl acetate, ethyl butyrate, ethyl hexanoate, and ethyl octanoate), medium-chain fatty acids (hexanoic, octanoic, and decanoic acids), and acetaldehyde $[83,85,86,89]$. Even though few studies are available on the OAVs in mead, the results show that they depend on the inoculum size, yeast cell immobilization, and nitrogen addition to fermentation, as well as on the yeast strain and honey used in the mead production.

\subsection{Sensory Evaluation of Mead}

Aroma volatile compounds play a key role in determining the quality of beverages because they are the primary contributors to aroma and produce an effect on sensory characteristics $[136,137]$. Two main types of methodologies are used for evaluation of the quality of food and beverages. The identification and quantification of aroma compounds, as an objective analysis technique, or subjective methods based on human assessment of the quality characteristics of the food [138]. Sensory analysis is indispensable for the assessment of food flavor characteristics to identify the significant sensory and quality contributors to food quality and consumer preference [139]. Overall, the more important sensory characteristics of beverages are the smell, the taste, and, to a lesser extent, the color [140], and their assessment is performed by a panel of experts or consumers. However, sensory perception is variable within individuals, the context of the consumer experience, and the chemical composition of the product [139].

Even though the identification and quantification of aroma compounds in mead produced under different conditions have been assessed [4,81-83,85,89,123,124], there is a lack of evidence regarding the sensory quality of the mead produced.

Koguchi et al. [114] produced mead with honey and black rice and performed the sensory test of the beverages, revealing that mead made from Chinese milk vetch honey was acceptable, while that produced using buckwheat honey was not very palatable. The sensory characteristics of mead produced with cassava (Manihot esculenta) floral honey under farm conditions in Nigeria was also assessed [92]. In this study, the expert test panel included nine food scientists, who commented freely on fresh and stored mead samples. The color and taste of the meads were generally acceptable and the 
characteristic aftertaste bitterness of samples was taken as both a positive and a negative attribute.

Vidrih and Hribar [124] studied the sensory properties of three different types of mead produced from chestnut, lime, and honeydew varieties of honey. The trained panelists chose the chestnut honey solution as the best raw material for mead production, followed by the lime and honeydew honey solutions. After fermentation, honey was added to meads and panelists preferred meads with $80 \mathrm{~g} / \mathrm{L}$ sugar over meads with $40 \mathrm{~g} / \mathrm{L}$ reducing sugar (dry mead with no reducing sugar is rather flat in taste and poor in body) and gave the best scores to the chestnut and lime meads. In the chestnut mead the reducing sugars masked the bitterness of the raw honey and the fermentation process improved the bouquet of the lime mead.

In short, the results of mead sensory analysis indicate that high sugar content is an important requisite to mead consumers.

The establishment of correlations between instrumental measurements of specific attributes and sensory characteristics may lead to a better understanding of the relationship between volatile composition and sensory properties, which is important to assess the quality of the beverage [139]. In this context, Roldán et al. [88] evaluated the influence of pollen addition on the sensory characteristics of mead, namely on visual (turbidity and color), aroma (quality and intensity), and taste (quality and intensity) characters, and verified that the aroma quality appeared to be related to the volatile compounds. The aroma of the control mead was described as floral (associated with 2phenylethanol) and vinegar-like acid (presence of 3-methylbutyric and hexanoic acids, ethyl acetate, and high total and volatile acidity), masking other aromas, which decreased the aroma quality. Mead with a high amount of pollen added was characterized by toasted, bitter almond, and honey scents that masked all other aromas, principally consistent with its high phenylacetaldehyde levels. Briefly, the pollen addition led to an increase in the volatile contents of meads, consequently improving its sensory profile.

\subsection{Conclusions and Perspectives}

Beekeeping is a dynamic activity in frank expansion in recent years. Even so, it is necessary to continue to valorize the honey and simultaneously find alternatives for the honey that cannot be commercialized. Thus, mead production may emerge as a great alternative for profit and to add value to honey not suitable for trading. Despite being a traditional alcoholic beverage made since ancient times, its production is still mostly empirical and homemade. The producers find several problems during fermentation, such as lack of uniformity in the final product, slow or premature fermentation arrest, and the production of off-flavors.

Owing to the lack of scientific progress in this area, research since 2005 has been dedicated to solving some of the problems associated with mead production. 
Most research has been focused on the type of honey, the honey must supplementation, and the fermentation conditions. Nevertheless studies related to the development of new production processes are scarce. For instance, the continuous fermentation process may emerge as an alternative, because, although the batch system has been the most used, it shows some deficiencies, in particular those related to low concentrations of reagents and the slow process of final product purification. Also, the application of immobilized yeasts, a technique with great potential and widely used in other beverages production, is not fully optimized in mead production. A previous study demonstrates that the use of multiple strains has a positive effect on mead fermentation, so it would be interesting to explore even further the use of mixed cultures.

In the same way, much is still unknown about the sensory analysis of mead. The studies available revealed that the tasters usually prefer a sweeter beverage. So, the research should also be focused on improving the sensory quality of mead, for example, by the addition of honey, fruit juices, or pollen at different stages of fermentation. The sensory quality of mead could also be improved with the aging, such as in oak vats. Owing to the absence of research in this area, it would be important to evaluate the effect of the aging process on the development of the aroma compounds of the beverage. However, to ensure a stable product and the safety of the consumer it is imperative to assess the shelf life of mead.

In conclusion, mead production is an area with limited research studies, so we consider that all the strategies proposed may contribute to obtaining a high-quality alcoholic beverage.

\section{Acknowledgments}

The research presented in this paper was partially funded by the Fundação para a Ciência e Tecnologia (FCT) and by PTDC projects (Contract PTDC/AGR-ALI/68284/2006). A.P. Pereira was a recipient of a Ph.D. grant from the FCT (SFRH/BD/45820/2008).

\section{References}

[1] R.W. Kime, R.A. Morse, K.H. Steinkraus, Mead: history, current technology and prospects, American Bee Journal 138 (2) (1998) 121-123.

[2] J.K. Gupta, R. Sharma, Production technology and quality characteristics of mead and fruit-honey wines: a review, Natural Product Radiance 8 (2009) 345-355.

[3] National Honey Board, Making Mead: The Art and the Science, 2001. Online in: http://www.honey. com/images/uploads/general/makingmead.pdf.

[4] P. Sroka, T. Tuszyński, Changes in organic acid contents during mead wort fermentation, Food Chemistry 104 (2007) 1250-1257.

[5] E.M. Morales, V.E. Alcarde, D.F. Angelis, Mead features fermented by Saccharomyces cerevisiae (lalvin k1-1116), African Journal of Biotechnology 12 (2) (2013) 199-204.

[6] D.S. McConnell, K.D. Schramm, Mead success: ingredients, processes and techniques, Zymurgy Spring 4 (1995) 33-39. 
[7] E.C. Ilha, E. Sant'Anna, R.C. Torres, A.C. Porto, E.M. Meinert, Utilization of bee (Apis mellifera) honey for vinegar production at laboratory scale, Acta Científica Venezolana 51 (2000) 231-235.C.

[8] Codex Alimentarius, Codex Standard for Honey (Codex Stan 12-1981 (Rev. 2-2001)), 2001.

[9] S. Bogdanov, T. Jurendic, R. Sieber, P. Gallmann, Honey for nutrition and health: a review, American Journal of the College of Nutrition 27 (2008) 677-689.

[10] X. Feás, J. Pires, A. Iglesias, M.L. Estevinho, Characterization of artisanal honey produced on the Northwest of Portugal by melissopalynological and physico-chemical data, Food and Chemical Toxicology 48 (2010) 3462-3470.

[11] M. Al-Mamary, A. Al-Meeri, M. Al-Habori, Antioxidant activities and total phenolics of different types of honey, Nutrition Research 22 (2002) 1041-1047.

[12] A. Mulu, B. Tessema, F. Derbie, In vitro assessment of the antimicrobial potential of honey on common human pathogens, Ethiopian Journal of Health Development 18 (2) (2004) 107-112.

[13] J.M. Alvarez-Suarez, M. Gasparrini, T.Y. Forbes-Hernández, L. Mazzoni, F. Giampieri, The composition and biological activity of honey: a focus on Manuka honey, Foods 3 (2014) 420-432.

[14] S. Bogdanov, The Honey Book, Chapter 5, 2011. Online in: http://www.academia.edu/5616849/ Composition_of_honey.

[15] J. Bertoncelj, U. Doberšek, M. Jamnik, T. Golob, Evaluation of the phenolic content, antioxidant activity and colour of Slovenian honey, Food Chemistry 105 (2007) 822-828.

[16] F. Buba, A. Gidado, A. Shugaba, Analysis of biochemical composition of honey samples from North-East Nigeria, Biochemistry and Analytical Biochemistry 2 (2013) 139. http://dx.doi.org/10. 4172/2161-1009.1000139.

[17] M.S. Finola, M.C. Lasagno, J.M. Marioli, Microbiological and chemical characterization of honeys from Central Argentina, Food Chemistry 100 (2007) 1649-1653.

[18] E. Anklam, A review of the analytical methods to determine the geographical and botanical origin of honey, Food Chemistry 63 (4) (1998) 549-562.

[19] D. Arráez-Román, A.M. Gómez-Caravaca, M. Gómez-Romero, A. Segura-Carratero, A. FernándezGutiérrez, Identification of phenolic compounds in rosemary honey using solid-phase extraction by capillary electrophoresis-electrospray ionization-mass spectrometry, Journal of Pharmaceutical and Biomedical Analysis 41 (2006) 1648-1656.

[20] L.C. Azeredo, M.A.A. Azeredo, S.R. Souza, V.M.L. Dutra, Protein contents and physicochemical properties in honey samples of Apis mellifera of different floral origins, Food Chemistry 80 (2003) 249-254.

[21] V. Baltrušaitytè, P.R. Venskutonis, V. Čeksterytė, Radical scavenging activity of different floral origin honey and beebread phenolic extracts, Food Chemistry 101 (2007) 502-514.

[22] L.S. Chua, J.Y. Lee, G.F. Chan, Characterization of the proteins in honey, Analytical Letters 48 (2015) 697-709.

[23] E. Kirs, R. Pall, K. Martverk, K. Laos, Physicochemical and melissopalynological characterization of Estonian summer honeys, Procedia Food Science 1 (2011) 616-624.

[24] M. Küçük, S. Kolailı, S. Karaoğlu, E. Ulusoy, C. Baltacı, F. Candan, Biological activities and chemical composition of three honeys of different types from Anatolia, Food Chemistry 100 (2007) 526-534.

[25] P.B. Olaitan, O.E. Adeleke, I.O. Ola, Honey: a reservoir for microorganisms and an inhibitory agent for microbes, African Health Sciences 7 (2007) 159-165.

[26] G.O. de Rodríguez, B.S. Ferrer, A. Ferrer, B. Rodríguez, Characterization of honey produced in Venezuela, Food Chemistry 84 (2004) 499-502.

[27] R. Fernández-Torres, J.L. Pérez-Bernal, M.A. Bello-López, M. Callejón-Mochón, J.C. JiménezSánchez, A. Guiraúm-Pérez, Mineral content and botanical origin of Spanish honeys, Talanta 65 (2005) 686-691. 
[28] M.C. Freitas, A.M.G. Pacheco, E. Ferreira, Nutrients and other elements in honey from Azores and mainland Portugal, Journal of Radioanalytical and Nuclear Chemistry 270 (2006) 123-130.

[29] S. Bogdanov, M. Haldimann, W. Luginbühl, P. Gallmann, Minerals in honey: environmental, geographical and botanical aspects, Journal of Apicultural Research and Bee World 46 (4) (2007) 269-275.

[30] M.E. Conti, J. Stripeikis, L. Campanella, D. Cucina, M.B. Tudino, Characterization of Italian honeys (Marche Region) on the basis of their mineral content and some typical quality parameters, Chemistry Central Journal 1 (2007) 14. http://dx.doi.org/10.1186/1752-153X-1-14.

[31] L.R. Silva, R. Videira, A.P. Monteiro, P. Valentão, P.B. Andrade, Honey from Luso region (Portugal): physicochemical characteristics and mineral contents, Microchemical Journal 93 (2009) 73-77.

[32] J.M. Alvarez-Suarez, S. Tulipani, S. Romandini, E. Bertoli, M. Battino, Contribution of honey in nutrition and human health: a review, Mediterranean Journal of Nutrition and Metabolism 3 (2010) 15-23.

[33] M.L. González-Miret, A. Terrab, D. Hernanz, M.A. Fernández-Recamales, F.J. Heredia, Multivariate correlation between color and mineral composition of honeys and by their botanical origin, Journal of Agricultural and Food Chemistry 53 (2005) 2574-2580.

[34] M.O. Iurlina, R. Fritz, Characterization of microorganisms in Argentinean honeys from different sources, International Journal of Food Microbiology 105 (2005) 297-304.

[35] S.R. Won, D.C. Lee, S.H. Ko, J.W. Kim, H.I. Rhee, Honey major protein characterization and its application to adulteration detection, Food Research International 41 (2008) 952-956.

[36] M. Ciulu, S. Solinas, I. Floris, A. Panzanelli, M.I. Pilo, P.C. Piu, N. Spano, G. Sanna, RP-HPLC determination of water-soluble vitamins in honey, Talanta 83 (2011) 924-929.

[37] V. León-Ruiz, S. Vera, A.V. González-Porto, M.P.S. Andrés, Analysis of water-soluble vitamins in honey by isocratic RP-HPLC, Food Analytical Methods 6 (2013) 488-496.

[38] L. Estevinho, A.P. Pereira, L. Moreira, L.G. Dias, E. Pereira, Antioxidant and antimicrobial effects of phenolic compounds extracts of Northeast Portugal honey, Food and Chemical Toxicology 46 (2008) 3774-3779.

[39] L. Yao, Y. Jiang, R. Singanusong, B. D’Arcy, N. Datta, N. Caffin, K. Raymont, Flavonoid in Australian Malaleuca, Guioa, Lophostemon, Banksia and Helianthus honeys and their potential for floral authentication, Food Research International 37 (2) (2004) 166-174.

[40] F.A. Tomás-Barberán, I. Martos, F. Ferreres, B.S. Radovic, E. Anklam, HPLC flavonoid profiles as markers for the botanical origin of European unifloral honeys, Journal of the Science of Food and Agriculture 81 (2001) 485-496.

[41] I. Escriche, M. Kadar, M. Juan-Borrás, E. Domenech, Using flavonoids, phenolic compounds and headspace volatile profile for botanical authentication of lemon and orange honeys, Food Research International 44 (2011) 1504-1513.

[42] M.L. Al, D. Daniel, A. Moise, O. Bobis, L. Laslo, S. Bogdanov, Physico-chemical and bioactive properties of different floral origin honeys from Romania, Food Chemistry 112 (2009) 863-867.

[43] H.A. Alzahrani, L. Boukraâ, Y. Bellik, F. Abdellah, B.A. Bakhotmah, S. Kolayli, H. Sahin, Evaluation of the antioxidant activity of three varieties of honey from different Botanical and geographical origins, Global Journal of Health Science 4 (6) (2012) 191-196.

[44] S.Ž. Gorjanović, J.M. Alvarez-Suarez, M.M. Novaković, F.T. Pastor, L. Pezo, M. Battino, D. Ž. Sužnjević, Comparative analysis of antioxidant activity of honey of different floral sources using recently developed polarographic and various spectrophotometric assays, Journal of Food Composition and Analysis 30 (2013) 13-18.

[45] R.K. Kishore, A.S. Halim, M.S.N. Syazana, K.N.S. Sirajudeen, Tualang honey has higher phenolic content and greater radical scavenging activity compared with other honey sources, Nutrition Research 31 (2011) 322-325. 
[46] A. Meda, C.E. Lamien, M. Romito, J. Millogo, O.G. Nacoulma, Determination of the total phenolic, flavonoid and proline contents in Burkina Fasan honey, as well as their radical scavenging activity, Food Chemistry 91 (2005) 571-577.

[47] Y. Ruiz-Navajas, M. Viuda-Martos, J. Fernández-López, J.M. Zaldivar-Cruz, V. Kuri, J.A. PérezÁlvarez, Antioxidant activity of artisanal honey from Tabasco, México, International Journal of Food Properties 14 (2011) 459-470.

[48] C. Basualdo, V. Sgroy, M.S. Finola, J.M. Marioli, Comparison of the antibacterial activity of honey from different provenance against bacteria usually isolated from skin wounds, Veterinary Microbiology 124 (2007) 375-381.

[49] A. Kumar, R. Kaushik, A. Kashyap, M.K. Kashyap, Indian honey: a natural product with antibacterial activity against antibiotic resistant pathogens, an "in vitro" study, Pakistan Journal of Biological Sciences 8 (2005) 190-193.

[50] P.E. Lusby, A.L. Coombes, J.M. Wilkinson, Bactericidal activity of different honeys against pathogenic bacteria, Archives of Medical Research 36 (2005) 464-467.

[51] A. Moussa, D. Noureddine, M. Abdelmelek, A. Saad, Antibacterial activity of various honey types of Algeria against pathogenic Gram-Negative bacilli: Escherichia coli and Pseudomonas aeruginosa, Asian Pacific Journal of Tropical Disease 2 (2012) 211-214.

[52] B.C. Nzeako, J. Hamdi, Antimicrobial potential of honey on some microbial isolates, Medical Sciences 2 (2000) 75-79.

[53] O. Sherlock, A. Dolan, R. Athman, A. Power, G. Gethin, S. Cowman, H. Humphreys, Comparison of the antimicrobial activity of Ulmo honey from Chile and Manuka honey against methicillinresistant Staphylococcus aureus, Escherichia coli and Pseudomonas aeruginosa, BMC Complementary and Alternative Medicine 10 (2010) 47.

[54] P.J. Taormina, B.A. Niemira, L.R. Beuchat, Inhibitory activity of honey against foodborne pathogens as influenced by the presence of hydrogen peroxide and level of antioxidant power, International Journal of Food Microbiology 69 (2001) 217-225.

[55] C. Voidarou, A. Alexopoulos, S. Plessas, A. Karapanou, I. Mantzourani, E. Stavropoulou, K. Fotou, A. Tzora, I. Skoufos, E. Bezirtzoglou, Antibacterial activity of different honeys against pathogenic bacteria, Anaerobe 17 (2011) 375-379.

[56] M.A. Mundo, O.I. Padilla-Zakour, R.W. Worobo, Growth inhibition of foodborne pathogens and food spoilage organisms by select raw honeys, International Journal of Food Microbiology 97 (2004) $1-8$.

[57] I. Escriche, M. Kadar, E. Domenech, L. Gil-Sánchez, A potentiometric electronic tongue for the discrimination of honey according to the botanical origin. Comparison with traditional methodologies: physicochemical parameters and volatile profile, Journal of Food Engineering 109 (2012) 449-456.

[58] C.E. Manyi-Loh, R.N. Ndip, A.M. Clarke, Volatile compounds in honey: a review on their involvement in aroma, botanical origin determination and potential biomedical activities, International Journal of Molecular Sciences 12 (2011) 9514-9532.

[59] L.F. Cuevas-Glory, J.A. Pino, L.S. Santiago, E. Sauri-Duch, A review of volatile analytical methods for determining the botanical origin of honey, Food Chemistry 103 (2007) 1032-1043.

[60] J.I. Cacho, N. Campillo, P. Viñas, M. Hernández-Córdoba, Evaluation of three headspace sorptive extraction coatings for thedetermination of volatile terpenes in honey using gaschromatographymass spectrometry, Journal of Chromatography A 1399 (2015) 18-24.

[61] L. Castro-Vázquez, M.C. Díaz-Maroto, M.A. González-Viñas, M.S. Pérez-Coello, Differentiation of monofloral citrus, rosemary, eucalyptus, lavender, thyme and heather honeys based on volatile composition and sensory descriptive analysis, Food Chemistry 112 (2009) 1022-1030. 
[62] V. Kaškonienè, P.R. Venskutonis, Floral markers in honey of various botanical and geographic origins: a review, Comprehensive Reviews in Food Science and Food Safety 9 (2010) 620-634.

[63] F. Bianchi, A. Mangia, M. Mattarozzi, M. Musci, Characterization of the volatile profile of thistle honey using headspace solid-phase microextraction and gas chromatography-mass spectrometry, Food Chemistry 129 (2011) 1030-1036.

[64] I. Jerković, C.I.G. Tuberoso, Z. Marijanović, M. Jelić, A. Kasum, Headspace, volatile and semivolatile patterns of Paliurus spina-christi unifloral honey as markers of botanical origin, Food Chemistry 112 (2009) 239-245.

[65] K.A. Aliferis, P.A. Tarantilis, P.C. Harizanis, E. Alissandrakis, Botanical discrimination and classification of honey samples applying gas chromatography/mass spectrometry fingerprinting of headspace volatile compounds, Food Chemistry 121 (2010) 856-862.

[66] I.K. Karabagias, A. Badeka, S. Kontakos, S. Karabournioti, M.G. Kontominas, Characterisation and classification of Greek pine honeys according to their geographical origin based on volatiles, physicochemical parameters and chemometrics, Food Chemistry 146 (2014) 548-557.

[67] I. Stanimirova, B. Üstün, T. Cajka, K. Riddelova, J. Hajslova, L.M.C. Buydens, B. Walczak, Tracing the geographical origin of honeys based on volatile compounds profiles assessment using pattern recognition techniques, Food Chemistry 118 (2010) 171-176.

[68] M. Juan-Borrás, E. Domenech, M. Hellebrandova, I. Escriche, Effect of country origin on physicochemical, sugar and volatile composition of acacia, sunflower and tilia honeys, Food Research International 60 (2014) 86-94.

[69] B.S. Radovic, M. Careri, A. Mangia, M. Musci, M. Gerboles, E. Anklam, Contribution of dynamic headspace GC-MS analysis of aroma compounds to authenticity testing of honey, Food Chemistry 72 (2001) 511-520.

[70] F. Bianchi, M. Careri, M. Musci, Volatile norisoprenoids as markers of botanical origin of Sardinian strawberry-tree (Arbutus unedo L.) honey: characterisation of aroma compounds by dynamic headspace extraction and gas chromatography-mass spectrometry, Food Chemistry 89 (2005) $527-532$.

[71] I. Odeh, S. Abu-Lafi, H. Dewik, I. Al-Najjar, A. Imam, V.M. Dembitsky, L.O. Hanuš, A variety of volatile compounds as markers in Palestinian honey from Thymus capitatus, Thymelaea hirsuta, and Tolpis virgata, Food Chemistry 101 (2007) 1393-1397.

[72] S. Gomes, L.G. Dias, L.L. Moreira, P. Rodrigues, L. Estevinho, Physicochemical, microbiological and antimicrobial properties of commercial honeys from Portugal, Food and Chemical Toxicology 48 (2010) 544-548.

[73] S. Shafiee, S. Minaei, N. Moghaddam-Charkari, M. Ghasemi-Varnamkhasti, M. Barzegar, Potential application of machine vision to honey characterization, Trends in Food Science and Technology 30 (2013) 174-177.

[74] M. Kačániová, M. Melich, V. Kňazovická, P. Haščík, J. Sudzinová, S. Pavličová, J. Čuboň, The indicator microorganisms value in relation to primary contamination of honey, Zootehnie si Biotehnologii 42 (2) (2009) 159-166.

[75] J.A. Snowdon, D.O. Cliver, Microorganisms in honey, International Journal of Food Microbiology 31 (1996) 1-26.

[76] N. Al-Waili, K. Salom, A. Al-Ghamdi, M.J. Ansari, Antibiotic, pesticide, and microbial contaminants of honey: human health hazards, The Scientific World Journal (2012) 1-9.

[77] M. Popa, M. Vica, R. Axinte, M. Glevitzky, S. Varvara, Study concerning the honey qualities in Transylvania region, Annales Universitatis Apulensis Series Oeconomica 11 (2) (2009) 1034-1040.

[78] T. Pota, K. Aruna, Microbiological analysis, biochemical composition and antibacterial activity of crude honey against multiple drug resistant uropathogens, Research Journal of Pharmaceutical, Biological and Chemical Sciences 4 (2013) 434-444. 
[79] M.J. Sereia, V.A.A. de Toledo, L.C. Marchini, E.M. Alves, P. Faquinello, T.C.S.O. Arnaut de Toledo, Microorganisms in organic and non organic honey samples of africanized bees, Journal of Apicultural Science 54 (2010) 49-54.

[80] V.L. Rall, A.J. Bombo, T.F. Lopes, L.R. Carvalho, M.G. Silva, Honey consumption in the state of São Paulo: a risk to human health? Anaerobe 9 (2003) 299-303.

[81] C.-H. Chen, Y.-L. Wu, D. Lo, M.-C. Wu, Physicochemical property changes during the fermentation of longan (Dimocarpus longan) mead and its aroma composition using multiple yeast inoculations, Journal of the Institute of Brewing 119 (2013) 303-308.

[82] A. Mendes-Ferreira, F. Cosme, C. Barbosa, V. Falco, A. Inês, A. Mendes-Faia, Optimization of honey-must preparation ad alcoholic fermentation by Saccharomyces cerevisiae for mead production, International Journal of Food Microbiology 144 (2010) 193-198.

[83] A.P. Pereira, A. Mendes-Ferreira, J.M. Oliveira, L.M. Estevinho, A. Mendes-Faia, High-cell-density fermentation of Saccharomyces cerevisiae for the optimisation of mead production, Food Microbiology 33 (2013) 114-123.

[84] A.P. Pereira, A. Mendes-Ferreira, L.M. Estevinho, A. Mendes-Faia, Mead production: fermentative performance of yeasts entrapped in different concentrations of alginate, Journal of the Institute of Brewing 120 (2014) 575-580.

[85] A.P. Pereira, A. Mendes-Ferreira, J.M. Oliveira, L.M. Estevinho, A. Mendes-Faia, Effect of Saccharomyces cerevisiae cells immobilisation on mead production, LWT - Food Science and Technology 56 (2014) 21-30.

[86] A.P. Pereira, A. Mendes-Ferreira, J.M. Oliveira, L.M. Estevinho, A. Mendes-Faia, Mead production: effect of nitrogen supplementation on growth, fermentation profile and aroma formation by yeasts in mead fermentation, Journal of the Institute of Brewing 121 (2015) 122-128.

[87] N. Qureshi, D.V. Tamhane, Mead production by continuous series reactors using immobilized yeast cells, Applied Microbiology and Biotechnology 23 (1986) 438-439.

[88] A. Roldán, G.C.J. van Muiswinkel, C. Lasanta, I. Caro, Influence of pollen addition on mead elaboration: physicochemical and sensory characteristics, Food Chemistry 126 (2011) 574-582.

[89] C.L. Wintersteen, L.M. Andrae, N.J. Engeseth, Effect of heat treatment on antioxidant capacity and flavor volatiles of mead, Journal of Food Science 70 (2005) 119-126.

[90] A.P. Pereira, T. Dias, J. Andrade, E. Ramalhosa, L.M. Estevinho, Mead production: selection and characterization assays of Saccharomyces cerevisiae strains, Food and Chemical Toxicology 47 (2009) 2057-2063.

[91] T. Gomes, C. Barradas, T. Dias, J. Verdial, J.S. Morais, E. Ramalhosa, L.M. Estevinho, Optimization of mead production using response surface methodology, Food and Chemical Toxicology 59 (2013) $680-686$.

[92] U.J. Ukpabi, Quality evaluation of meads produced with Cassava (Manihot esculenta) floral honey under farm conditions in Nigeria, Tropical and Subtropical Agroecosystems 6 (2006) 37-41.

[93] M. Navrátil, E. Sturdík, P. Gemeiner, Batch and continuous mead production with pectate immobilised, ethanol-tolerant yeast, Biotechnology Letters 23 (2001) 977-982.

[94] J.X. Castillo-Sánchez, M.S. García-Falcón, J. Garrido, E. Martínez-Carballo, L.R. Martins-Dias, X.C. Mejuto, Phenolic compounds and colour stability of Vinhão wines: influence of wine-making protocol and fining agents, Food Chemistry 106 (2008) 18-26.

[95] B. Boulton, V.L. Singleton, L.F. Bisson, R.E. Kunkee, Principles and Practices of Winemaking, Chapman and Hall, New York, 1996.

[96] A. Mendes-Ferreira, C. Barbosa, P. Lage, A. Mendes-Faia, The impact of nitrogen on yeast fermentation and wine quality, Ciência e Técnica Vitivinícola 26 (2011) 17-32. 
[97] H.J. Phaff, M.W. Miller, M. Mrak, in: The Life of Yeasts, second ed., Harvard University Press, Cambridge, Massachusetts, 1978.

[98] E. Ramalhosa, T. Gomes, A.P. Pereira, T. Dias, L.M. Estevinho, Mead production: tradition versus modernity, in: R.S. Jackson (Ed.), Advances in Food and Nutrition Research, Academic Press, Burlington, 2011, pp. 101-118.

[99] Y. Teramoto, R. Sato, S. Ueda, Characteristics of fermentation yeast isolated from traditional Ethiopian honey wine, ogol, African Journal of Biotechnology 4 (2005) 160-163.

[100] B. Bahiru, T. Mehari, M. Ashenafi, Yeast and lactic acid flora of $t e j$, an indigenous Ethiopian honey wine: variations within and between production units, Food Microbiology 23 (2006) 277-282.

[101] G.H. Fleet, Yeast interactions and wine flavour, International Journal of Food Microbiology 86 (2003) 11-22.

[102] F. Carrau, K. Medina, L. Fariña, E. Boido, E. Dellacassa, Effect of Saccharomyces cerevisiae inoculum size on wine fermentation aroma compounds and its relation with assimilable nitrogen content, International Journal of Food Microbiology 143 (2010) 81-85.

[103] B.R. Gibson, Improvement of higher gravity brewery fermentation via wort enrichment and supplementation, Journal of the Institute of Brewing 117 (2011) 268-284.

[104] S. Alfenore, C. Molina-Jouve, S.E. Guillouet, J.L. Uribelarrea, G. Goma, L. Benbadis, Improving ethanol production and viability of Saccharomyces cerevisiae by a vitamin feeding strategy during fed-batch process, Applied Microbiology and Biotechnology 60 (2002) 67-72.

[105] J.M. Sablayrolles, Control of alcoholic fermentation in winemaking: current situation and prospect, Food Research International 42 (2009) 418-424.

[106] F.B. Pereira, P.M.R. Guimarães, J.A. Teixeira, L. Domingues, Optimization of low-cost medium for very high gravity ethanol fermentations by Saccharomyces cerevisiae using statistical experimental designs, Bioresource Technology 101 (2010) 7856-7863.

[107] G. Beltran, B. Esteve-Zarzoso, N. Rozès, A. Mas, J.M. Guilllamón, Influence of the timing of nitrogen additions during synthetic grape must fermentations on fermentation kinetics and nitrogen consumption, Journal of Agriculture and Food Chemistry 53 (2005) 996-1002.

[108] M. Bely, J.M. Salmon, P. Barre, Assimilable nitrogen addition and hexose transport system activity during enological fermentation, Journal of the Institute of Brewing 100 (1994) 279-282.

[109] L. Crépin, T. Nidelet, I. Sanchez, S. Dequin, C. Camarasa, Sequential use of nitrogen compounds by Saccharomyces cerevisiae during wine fermentation: a model based on kinetic and regulation characteristics of nitrogen permeases, Applied and Environmental Microbiology 78 (2012) 8102-8111.

[110] D. Torrea, C. Varela, M. Ugliano, C. Ancin-Azpilicueta, I.L. Francis, Comparison of inorganic and organic nitrogen supplementation of grape juice - effect on volatile composition and aroma profile of a Chardonnay wine fermented with Saccharomyces cerevisiae yeast, Food Chemistry 127 (2011) 1072-1083.

[111] A. Mendes-Ferreira, A. Mendes-Faia, C. Leão, Growth and fermentation patterns of Saccharomyces cerevisiae under different ammonium concentrations and its implications in winemaking industry, Journal of Applied Microbiology 97 (2004) 540-545.

[112] C. Manginot, J.L. Roustan, J.M. Sablayrolles, Nitrogen demand of different yeast strains during alcoholic fermentation. Importance of the stationary phase, Enzyme and Microbial Technology 23 (1998) 511-517.

[113] R. Martínez-Moreno, P. Morales, R. Gonzales, A. Mas, G. Beltran, Biomass production and alcoholic fermentation performance of Saccharomyces cerevisiae as a function of nitrogen source, FEMS Yeast Research 12 (2012) 477-485. 
[114] M. Koguchi, N. Saigusa, Y. Teramoto, Production and antioxidative activity of mead made from honey and black rice (Oryza sativa var. Indica cv. Shiun), Journal of the Institute of Brewing 115 (3) (2009) 238-242.

[115] Y. Kourkoutas, A. Bekatorou, I.M. Banat, R. Marchant, A.A. Koutinas, Immobilization technologies and support materials suitable in alcohol beverages production: a review, Food Microbiology 21 (2004) 377-397.

[116] C. Diviès, R. Cachon, Wine production by immobilised cell systems, in: V. Nedović, R. Willaert (Eds.), Applications of Cell Immobilisation Biotechnology, Springer, Netherlands, 2005, pp. 285-293.

[117] Z. Genisheva, J.A. Teixeira, J.M. Oliveira, Immobilized cell systems for batch and continuous winemaking, Trends in Food Science and Technology 40 (1) (2014) 33-47.

[118] P.H. Pilkington, A. Margaritis, N.A. Mensour, I. Russel, Fundamentals of immobilised yeast cells for continuous beer fermentation: a review, Journal of the Institute of Brewing 104 (1998) 19-31.

[119] N. Qureshi, D.V. Tamhane, Production of mead by immobilized whole cells of Saccharomyces cerevisiae, Applied Microbiology and Biotechnology 21 (1985) 280-281.

[120] D. Anupama, K.K. Bhat, V.K. Sapna, Sensory and physico-chemical properties of commercial samples of honey, Food Research International 36 (2003) 183-191.

[121] L. Castro-Vázquez, M.C. Díaz-Maroto, C. de Torres, M.S. Pérez-Coello, Effect of geographical origin on the chemical and sensory characteristics of chestnut honeys, Food Research International 43 (2010) 2335-2340.

[122] M. Vilanova, J.M. Oliveira, Application of gas chromatography on the evaluation of grape and wine aroma in Atlantic viticulture (NW Iberian Peninsula), in: B. Salih, O. Celikbicak (Eds.), Gas Chromatography in Plant Science, Wine Technology, Toxicology and Some Specific Applications, InTech, 2012, pp. 109-146.

[123] D. Šmogrovičová, P. Nádaský, R. Tandlich, B.S. Wilhelmi, G. Cambray, Analytical and aroma profiles of Slovak and South African meads, Czech Journal of Food Science 30 (3) (2012) 241-246.

[124] R. Vidrih, J. Hribar, Studies on the sensory properties of mead and the formation of aroma compounds related to the type of honey, Acta Alimentaria 36 (2007) 151-162.

[125] J.H. Swiegers, E.J. Bartowsky, P.A. Henschke, I.S. Pretorius, Yeast and bacterial modulation of wine aroma and flavour, Australian Journal of Grape and Wine Research 11 (2005) 139-173.

[126] M. Ugliano, P.A. Henschke, Yeasts and wine flavour, in: M.V. Moreno-Arribas, M.C. Polo (Eds.), Wine Chemistry and Biochemistry, Springer Science+Business Media, LLC, 2009, pp. 313-392.

[127] H. Guth, Quantification and sensory studies of character impact odorants of different white wine varieties, Journal of Agricultural and Food Chemistry 45 (8) (1997) 3027-3032.

[128] J.A. Moreno, L. Zea, L. Moyano, M. Medina, Aroma compounds as markers of the changes in sherry wines subjected to biological ageing, Food Control 16 (2005) 333-338.

[129] E.J. Bartowsky, I.S. Pretorius, Microbial formation and modification of flavor and off-flavor compounds in wine, in: H. König, et al. (Eds.), Biology of Microorganisms on Grapes, in Must and in Wine, Springer-Verlag, Berlin Heidelberg, 2009, pp. 209-231.

[130] M.C. Meilgaard, Flavor chemistry of beer: part II: flavor and threshold of 239 aroma volatiles, MBAA Technical Quarterly 12 (1975) 151-168.

[131] A. Escudero, B. Gogorza, M.A. Melús, N. Ortín, J. Cacho, V. Ferreira, Characterization of the aroma of a wine from Maccabeo. Key role played by compounds with low odor activity values, Journal of Agricultural and Food Chemistry 52 (11) (2004) 3516-3524.

[132] B. Švecová, M. Bordovská, D. Kalvachová, T. Hájek, Analysis of Czech meads: sugar content, organic acids content and selected phenolic compounds content, Journal of Food Composition and Analysis 38 (2015) 80-88. 
[133] V. Ferreira, R. López, J.F. Cacho, Quantitative determination of the odorants of young red wines from different grape varieties, Journal of Science and Food Agriculture 80 (2000) 1659-1667.

[134] L. Nykänen, Formation and occurrence of flavour compounds in wine and distilled alcoholic beverages, American Journal of Enology and Viticulture 37 (1) (1986) 84-96.

[135] M. Czerni, M. Christlbauer, M. Christlbauer, A. Fischer, M. Granvogl, M. Hammer, C. Hartl, N.M. Hernandez, P. Schieberle, Re-investigation on odour thresholds of key food aroma compounds and development of an aroma language based on odour qualities of defined aqueous odorant solutions, European Food Research and Technology 228 (2008) 265-273.

[136] A.J. Andreu-Sevilla, P. Mena, N. Martí, C.G. Viguera, A.A. Carbonell-Barrachina, Volatile composition and descriptive sensory analysis of pomegranate juice and wine, Food Research International 54 (2013) 246-254.

[137] M. Vilanova, Z. Genisheva, A. Masa, J.M. Oliveira, Correlation between volatile composition and sensory properties in Spanish Albariño wines, Microchemical Journal 95 (2010) 240-246.

[138] H. Smyth, D. Cozzolino, Instrumental methods (spectroscopy, electronic nose, and tongue) as tools to predict taste and aroma in beverages: advantages and limitations, Chemical Reviews 113 (3) (2013) 1429-1440.

[139] L.M. Schmidtke, A. Rudnitskaya, A.J. Saliba, J.W. Blackman, G.R. Scollary, A.C. Clarck, D.N. Rutledge, I. Delgadillo, A. Legin, Sensory, chemical, and electronic tongue assessment of microoxygenated wines and oak chip maceration: assessing the commonality of analytical techniques, Journal of Agricultural and Food Chemistry 58 (2010) 5026-5033.

[140] A.L. Robinson, P.K. Boss, H. Heymann, P.S. Soloman, R.D. Trengove, Influence of yeast strain, canopy management, and site on the volatile composition and sensory attributes of Cabernet Sauvignon wines from Western Australia, Journal of Agricultural and Food Chemistry 59 (2011) $3273-3284$. 